\title{
Chemical control of winter wheat and its influence on yield and economic indexes in Podkarpacie
}

\author{
Chemiczna ochrona pszenicy ozimej oraz jej wpływ \\ na plon ziarna i wskaźniki ekonomiczne na Podkarpaciu
}

\author{
Zdzisław Kaniuczak*, Łukasz Siekaniec
}

\section{Summary}

The studies on the economic efficiency of fungicides and insecticides used in winter wheat crops were conducted in 2012-2014 in Boguchwała. An average per cent of leaf area infected by pathogens was $80.3 \%$ and the damage caused by pests was on average $14.5 \%$. The effectiveness of applied pesticides ranged from 8.0 to $86.2 \%$ for fungicides and from 31.8 to $89.2 \%$ for insecticides. Surplus of the saved wheat production ranged from 6.5 to $1222 \mathrm{PLN} /$ ha. The cost coverage index ranged from 0.01 to 7.4 , whereas the treatment profitability index ranged from 1.0 to 19.4. The percentage cost index ranged from 1.2 to 54.0.

Key words: winter wheat; diseases; pests; chemical control; economic index

\section{Streszczenie}

Badania nad efektywnością ekonomiczną zastosowanych fungicydów oraz insektycydów w pszenicy ozimej wykonano w latach 2012-2014 w Boguchwale. Średnie porażenie powierzchni liści przez choroby pszenicy wyniosło 80,3\%, a uszkodzenie przez szkodniki14,5\%. Skuteczność zastosowanych środków grzybobójczych wyniosła od 8,0 do 86,2\%, a insektycydów od 31,8 do 89,2\%. Nadwyżka produkcji wahała się od 6,5 do 1222 PLN/ha. Wskaźnik pokrycia kosztów wyniósł od 0,01 do 7,4, a wskaźnik opłacalności zabiegów od 1,0 do 19,4. Procentowy wskaźnik kosztów wahał się od 1,2 do 54,0.

Słowa kluczowe: pszenica ozima; choroby; szkodniki; ochrona chemiczna; wskaźniki ekonomiczne

\footnotetext{
Instytut Ochrony Roślin - Państwowy Instytut Badawczy

Terenowa Stacja Doświadczalna

Langiewicza 28, 35-101 Rzeszów

*corresponding author: z.kaniuczak@iorpib.poznan.pl
} 


\section{Wstęp / Introduction}

Jednym $\mathrm{z}$ zagrożeń powodujących straty ilościowe i jakościowe plonu są grzyby, które przez cały okres wegetacji powodować mogą choroby uprawianych roślin (Korbas 1998; Lipa 1999; Walczak 2010). Ich ograniczenie jest możliwe poprzez stosowanie zaplanowanej ochrony uwzględniającej metody agrotechniczne oraz zabiegi chemiczne. W nowoczesnych technologiach rolniczych, według Golinowskiej (2009), chemiczne zabiegi ochrony roślin są nakładem niezbędnym, ponieważ zabezpieczają plon przed stratą.

Opanowanie zbóż przez choroby i szkodniki powoduje znaczne straty w plonach ziarna oraz pogorszenie jego jakości, stąd też ważnym staje się prowadzenie badań nad zwalczaniem najważniejszych chorób i szkodników przy zróżnicowanym ich nasileniu, jak również bieżąca analiza uzyskiwanych efektów ekonomicznych wykonywanych zabiegów.

Celem badań była ocena skuteczności oraz efektywności ekonomicznej wybranych fungicydów i insektycydów w zwalczaniu chorób powodowanych przez grzyby patogeniczne, a także larw skrzypionek w uprawie pszenicy ozimej w doświadczeniach polowych.

\section{Materiały i metody / Materials and methods}

Badania wykonano w latach 2012-2014 na polach doświadczalnych Podkarpackiego Ośrodka Doradztwa

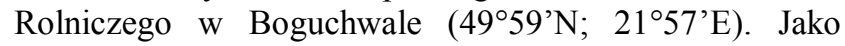
materiał siewny użyta została pszenica ozima odmiany Smuga, która dobrze i wiernie plonuje na terenie całego kraju. Odmiana ta jest średnio odporna na choroby powodowane przez grzyby chorobotwórcze. Doświadczenie założono metodą bloków losowanych w czterech powtórzeniach, na poletkach o wymiarach $11 \mathrm{~m} \times$ 1, $5 \mathrm{~m}$. Przedplonem dla pszenicy były rośliny strączkowe. Siew pszenicy wykonano na glebie kompleksu pszennego dobrego, klasa bonitacyjna gleby II. Nasiona zaprawiono w latach 2012 i 2013 zaprawą Funaben T 75 DS/WS (karbendazym, tiuram) w dawce $200 \mathrm{ml} / 100 \mathrm{~kg}$ nasion, natomiast w 2014 roku zaprawą Funaben Plus 02 WS (tebukonazol) w dawce $150 \mathrm{~g} / 100 \mathrm{~kg}$ ziarna. Stosowano następujące nawożenie: $\mathrm{N}-98 \mathrm{~kg} / \mathrm{ha} ; \mathrm{P}_{2} \mathrm{O}_{5}-60 \mathrm{~kg} / \mathrm{ha}$; $\mathrm{K}_{2} \mathrm{O}-90 \mathrm{~kg} / \mathrm{ha}$. Wszystkie kombinacje doświadczalne były tak samo traktowane herbicydami w celu zwalczania chwastów. Obiekt kontrolny stanowiły poletka nieopryskiwane fungicydami oraz insektycydami.

Nasilenie występowania chorób i szkodników analizowano podczas wegetacji pszenicy zgodnie $\mathrm{z}$ metodą opisaną przez Lisowicza i wsp. (1993). W celu zwalczania chorób i szkodników występujących na roślinach w uprawie pszenicy zastosowano trzy zabiegi: I - wiosną w fazie wzrostu roślin BBCH 30-32 (początek wzrostu źdźbła - faza 2 kolanka) zastosowano Alert 375 SC (flusilazol + karbendazym) w dawce 1,0 1/ha, II - przed kwitnieniem - w fazie wzrostu BBCH 51-59 (początek kłoszenia - zakończenie fazy kłoszenia) użyto Artea $330 \mathrm{EC}$ (propikonazol + cyprokonazol) w dawce 0,5 1/ha,
III - w okresie wypełniania ziarna pszenicy BBCH 69-71 (koniec fazy kwitnienia - dojrzałość wodna) wykorzystano Mirage 450 EC (prochloraz) w dawce 1,0 1/ha.

W zwalczaniu szkodników użyto następujące insektycydy: Karate 050 CS (lambda-cyhalotryna) w dawce $0,1 \mathrm{l} / \mathrm{ha}$, Sumi-Alpha 050 EC (esfenwalerat) w dawce $0,25 \mathrm{l} / \mathrm{ha}$, Fastac $100 \mathrm{EC}$ (alfa-cypermetryna) w dawce 0,1 1/ha, Biospin $120 \mathrm{SC}$ (spinosad) w dawce 1,5 1/ha. Zabiegi wykonano przy użyciu opryskiwacza ciśnieniowego Ap/1Np, stosując $300 \mathrm{dm}^{3}$ cieczy na hektar.

Ocenę porażenia pszenicy przez grzyby chorobotwórcze oraz uszkodzeń powodowanych przez szkodniki, wykonano określając procent porażenia powierzchni dwóch górnych liści: flagowego i podflagowego na 100 źdźbłach z każdej kombinacji doświadczalnej w fazie dojrzałości mlecznej (BBCH 73-77). Po osiągnięciu przez rośliny dojrzałości pełnej, przeprowadzono zbiór określając plon ziarna i masę tysiąca ziaren (MTZ). Oznaczono wilgotność ziarna i otrzymane plony przeliczano na $14 \%$ wilgotności. Istotność różnic oceniano pomiędzy średnimi testem Duncana przy 5\% poziomie istotności.

W analizie ekonomicznej opłacalności chemicznego zwalczania szkodników i chorób wyliczono następujące wskaźniki: Wpk - wskaźnik pokrycia kosztów (określający stosunek wartości produkcji uratowanego plonu do kosztów zabiegu), $\mathrm{E}_{1}$ - wskaźnik opłacalności zabiegów, $\mathrm{E}_{2}$ - procentowy wskaźnik kosztów (Golinowska 2009). Do obliczenia wyżej wymienionych wskaźników, dla danego roku badań, przyjęto średnie ceny ziarna pszenicy, zastosowanych środków ochrony roślin oraz koszt wykonania zabiegów.

\section{Wyniki i dyskusja / Results and discussion}

\section{Warunki meteorologiczne}

Warunki meteorologiczne podczas prowadzenia badań były zróżnicowane w latach 2012-2014 (tab. 1).

W 2012 roku począwszy od kwietnia do pierwszej połowy maja zanotowano znaczną liczbę dni z niskimi temperaturami (zwłaszcza nocą), które początkowo ograniczały intensywny wzrost roślin. Od drugiej połowy maja natomiast odnotowano wyraźny wzrost temperatury, który sprzyjał rozwojowi roślin pszenicy. Pod względem opadów rok ten należał do stosunkowo suchych, jednak nie odnotowano w rejonie prowadzonych badań objawów niedoboru wilgoci na roślinach pszenicy.

W 2013 roku początek wiosny był opóźniony o dwa tygodnie. Ruszenie wegetacji rozpoczęło się w pierwszych dniach kwietnia. Druga połowa kwietnia była bez opadów i z temperaturą sprzyjającą wegetacji ozimin. W okresie maja i czerwca warunki pogodowe, szczególnie temperaturowe, sprzyjały rozwojowi roślin pszenicy.

W 2014 roku zima była łagodna z małą ilością opadów śniegu. Wczesna wiosna pozwoliła wykonać zabiegi uprawowe w terminach agrotechnicznych. Wysokie temperatury występujące w kwietniu przyczyniły się do szybkiego wzrostu zbóż. Warunki pogodowe w maju i czerwcu sprzyjały rozwojowi grzybów patogenicznych oraz szkodników. 
Tabela 1. Przebieg warunków pogodowych w Rzeszowie - Jasionce, w latach 2012-2014

Table 1. Weather conditions in 2012-2014, in Rzeszów - Jasionka

\begin{tabular}{|c|c|c|c|c|c|c|c|}
\hline \multirow{2}{*}{$\begin{array}{l}\text { Miesiąc } \\
\text { Month }\end{array}$} & \multirow{2}{*}{$\begin{array}{l}\text { Dekada } \\
\text { Decade }\end{array}$} & \multicolumn{3}{|c|}{$\begin{array}{c}\text { Średnia temperatura powietrza } \\
\text { Mean air temperature }\end{array}$} & \multicolumn{3}{|c|}{$\begin{array}{c}\text { Suma opadów - Rainfall sum } \\
{[\mathrm{mm}]}\end{array}$} \\
\hline & & 2012 & 2013 & 2014 & 2012 & 2013 & 2014 \\
\hline \multirow{4}{*}{$\begin{array}{l}\text { Kwiecień } \\
\text { April }\end{array}$} & I & 4,8 & 1,7 & 8,5 & 15,5 & 24,4 & 16,1 \\
\hline & II & 9,6 & 11,1 & 8,0 & 6,2 & 7,6 & 2,1 \\
\hline & III & 14,8 & 15,3 & 13,6 & 4,4 & 1,9 & 9,5 \\
\hline & $\begin{array}{c}\text { średnia/suma } \\
\text { miesięczna } \\
\text { mean/sum monthly }\end{array}$ & 9,7 & 9,3 & 10,0 & 26,1 & 33,9 & 27,7 \\
\hline \multirow{4}{*}{$\begin{array}{l}\text { Maj } \\
\text { May }\end{array}$} & I & 15,3 & 10,7 & 11,6 & 24,3 & 26,3 & 8,1 \\
\hline & II & 12,3 & 11,0 & 12,8 & 30,1 & 0,5 & 59,8 \\
\hline & III & 16,7 & 7,6 & 17,3 & 1,6 & 60,7 & 19,3 \\
\hline & $\begin{array}{c}\text { średnia/suma } \\
\text { miesięczna } \\
\text { mean/sum monthly }\end{array}$ & 14,7 & 9,7 & 13,9 & 56,0 & 87,5 & 87,2 \\
\hline \multirow{4}{*}{$\begin{array}{l}\text { Czerwiec } \\
\text { June }\end{array}$} & $\mathrm{I}$ & 15,8 & 16,8 & 17,6 & 43,8 & 78,6 & 3,3 \\
\hline & II & 19,6 & 20,0 & 18,5 & 31,4 & 25,3 & 12,5 \\
\hline & III & 19,7 & 18,6 & 16,1 & 8,4 & 39,5 & 32,2 \\
\hline & $\begin{array}{c}\text { średnia/suma } \\
\text { miesięczna } \\
\text { mean/sum monthly }\end{array}$ & 18,3 & 18,4 & 17,4 & 83,6 & 143,4 & 48,0 \\
\hline \multirow{4}{*}{$\begin{array}{c}\text { Lipiec } \\
\text { July }\end{array}$} & I & 24,8 & 19,6 & 19,3 & 6,1 & 0,1 & 36,8 \\
\hline & II & 18,3 & 17,5 & 20,2 & 20,1 & 19,1 & 43,4 \\
\hline & III & 20,8 & 20,8 & 21,6 & 27,3 & 0,0 & 48,4 \\
\hline & $\begin{array}{c}\text { średnia/suma } \\
\text { miesięczna } \\
\text { mean/sum monthly }\end{array}$ & 21,3 & 19,3 & 20,3 & 53,5 & 19,2 & 128,6 \\
\hline \multirow{4}{*}{$\begin{array}{l}\text { Sierpień } \\
\text { August }\end{array}$} & I & 21,6 & 23,2 & 21,7 & 2,6 & 0,0 & 12,2 \\
\hline & II & 16,5 & 19,4 & 18,3 & 35,3 & 3,0 & 32,7 \\
\hline & III & 18,9 & 15,8 & 14,7 & 18,4 & 8,0 & 31,8 \\
\hline & $\begin{array}{c}\text { średnia/suma } \\
\text { miesięczna } \\
\text { mean/sum monthly }\end{array}$ & 19,0 & 19,4 & 18,2 & 56,3 & 11,0 & 76,7 \\
\hline
\end{tabular}

\section{Występowanie chorób i szkodników}

Panujące w latach badań warunki pogodowe oraz średnia odporność na choroby odmiany Smuga powodowały, że rośliny pszenicy ozimej ulegały porażeniu przez: mączniaka prawdziwego zbóż i traw [Blumeria graminis (DC) Spaer.], rdzę brunatną (Puccinia recondita), septoriozę liści (Septoria tritici) i fuzariozę kłosów (Fusarium spp.). W latach badań największe zniszczenia powierzchni blaszek liściowych stwierdzano w wyniku wystąpienia septoriozy liści i rdzy brunatnej.

Na roślinach pszenicy występowały również szkodniki: skrzypionki (Oulema spp.), mszyce (Aphididae), wciornastki (Thysanoptera), ploniarka zbożówka (Oscinella frit L.), niezmiarka paskowana (Chlorops pumilionis Bjerk.) oraz pryszczarkowate (Cecidomyiidae). W latach badań w największym nasileniu występowały skrzypionki, w słabym mszyce i wciornastki, a inne owady w bardzo słabym nasileniu. W niektóre lata roślinom pszenicy oprócz skrzypionek mogą zagrażać również mszyce, miniarki, niezmiarka paskowana, ploniarka zbożówka oraz pryszczarkowate, o czym donoszą autorzy prowadzący badania w różnych regionach kraju (Pokacka 1985; Jańczak i wsp. 1990; Wałkowski i wsp. 2000; Kaniuczak 2008; Walczak 2010).

Warunki meteorologiczne mają również duży wpływ na występowanie i rozwój grzybów patogenicznych. Duża ilość opadów i wysoka wilgotność względna powietrza w czasie wegetacji, istotnie różnicują porażenie roślin przez patogeny liści i kłosów, plon ziarna i masę tysiąca ziaren pszenicy (King i wsp. 1983; Głazek i wsp. 2006; Jaczewska-Kalicka 2008). Nawet w latach o przebiegu niesprzyjającym ich rozwojowi stosowanie fungicydów zwiększa plony pszenicy o 3-19\% (Jaczewska 1993). W warunkach sprzyjających rozwojowi chorób stwierdzono zarówno większą powierzchnię liści zniszczonych przez grzyby chorobotwórcze, jak również odnotowano lepszą efektywność zastosowanych fungicydów (Danyte i Pecio 2009). 


\section{Ocena ekonomiczna zabiegów ochrony roślin}

Wyniki badań własnych nad chemicznym zwalczaniem chorób i szkodników oraz wpływem zabiegów ochrony roślin na plon ziarna pszenicy przedstawiono $\mathrm{w}$ tabeli 2 . W 2012 roku porażenie liści pszenicy przez sprawców chorób na obiekcie kontrolnym było wysokie i wyniosło średnio 77,7\%. Larwy skrzypionek uszkodziły w tym okresie średnio 16,0\% liści. Zastosowane fungicydy ograniczyły stopień porażenia liści na poziomie od 39,0 do $86,2 \%$, natomiast użyte insektycydy zmniejszyły powierzchnię uszkodzonych liści średnio o 75,0\%. Zwyżka plonów ziarna pszenicy $\mathrm{w}$ stosunku do kontroli wahała się od $1,0 \mathrm{do} 14,0 \mathrm{dt} / \mathrm{ha}$ (średnio o $8,7 \%$ ). Zastosowanie fungicydów wpłynęło na istotną zwyżkę plonu ziarna i MTZ pszenicy.

W 2013 roku porażenie liści pszenicy w kombinacji kontrolnej przez grzyby chorobotwórcze utrzymywało się na poziomie wysokim i wynosiło $88,3 \%$, a uszkodzenie przez larwy skrzypionek wyniosło średnio $11,0 \%$. Zastosowanie fungicydów pozwoliło ograniczyć procent porażenia powierzchni liści przez sprawców chorób na poziomie od 8,0 do $80,0 \%$ porażonej powierzchni liścia flagowego i podflagowego, natomiast użycie insektycydów ograniczyło uszkodzenie powodowane przez skrzypionki średnio o 52,8\%. Zwyżka plonów ziarna pszenicy na obiektach chronionych w stosunku do kontroli wyniosła od $0,1 \mathrm{do} 18,8 \mathrm{dt} / \mathrm{ha}$ (średnio $20,2 \%$ ). Zastosowanie zabiegów fungicydowych wpłynęło na istotne zwiększenie plonu ziarna oraz MTZ pszenicy ozimej.

W 2014 roku porażenie liści przez grzyby chorobotwórcze w kombinacji kontrolnej utrzymywało się na poziomie wysokim i wynosiło $75,0 \%$, a uszkodzenie przez larwy skrzypionek wyniosło średnio $16,6 \%$. Zastosowane fungicydy ograniczyły procent porażonej powierzchni liści na poziomie od 17,6 do $68,0 \%$, natomiast użyte insektycydy zmniejszyły powierzchnię uszkodzonych liści średnio o 85,6\%. Zwyżka plonów ziarna pszenicy w stosunku do kontroli wynosiła od 0,1 do $8,69 \mathrm{dt} / \mathrm{ha}$ (średnio o 7,4\%). Zastosowanie fungicydów nie wpłynęło na istotną zwyżkę plonu ziarna i MTZ pszenicy.

Zwalczanie chorób powodowanych przez grzyby jest zabiegiem warunkującym uzyskanie wysokich plonów pszenicy oraz poprawę jego jakości. Ochrona przed chorobami powodowanymi przez grzyby chorobotwórcze traktowana jest jako nieodzowny element agrotechniki. Dodatkowo chemiczna ochrona pozwala na efektywne wykorzystanie innych elementów, takich jak nawożenie (Jończyk 1999).

Zabiegi wykonane przy użyciu fungicydów niezwykle korzystnie wpływały na zdrowotność liści i źdźbła. Lepsze efekty uzyskiwano po zastosowaniu dwóch zabiegów, jednak już jeden zabieg zdecydowanie zmniejszał procent porażonej powierzchni najwyższych liści i zwiększał plon. Zastosowane zabiegi fungicydowe we wszystkich latach wpływały na utrzymanie „efektu zieloności” górnych liści pszenicy ozimej. Prowadzone badania przez Podolską i Szypułę (2002) wskazują, że uzyskanie ziarna o wymaganych parametrach technologicznych jest możliwe po wykonaniu zabiegów chemicznej ochrony zasiewów pszenicy w gospodarstwach rolnych.
Efekty ekonomiczne stosowania insektycydów i fungicydów w pszenicy przedstawiono w tabeli 3 .

W 2012 roku efektywność produkcyjna zabiegów uzyskana na poszczególnych obiektach pszenicy wyrażona wartością plonu uratowanego wahała się od 85 do $1190 \mathrm{PLN} / \mathrm{ha}$ (średnio $560 \mathrm{PLN} / \mathrm{ha}$ ). Wskaźnik pokrycia kosztów wyniósł od 0,1 do 4,0. Najkorzystniejszą wartość otrzymano $\mathrm{z}$ obiektu, na którym zastosowano $\mathrm{w}$ fazie kłoszenia pszenicy fungicyd Artea 330 EC. Natomiast najniższą wartość uzyskano, gdy zastosowano Biospin 120 SL. Koszty poniesione na ochronę chemiczną zwróciły się w niewielkim stopniu. Zdecydowała o tym niska zwyżka plonu ziarna pszenicy oraz wysoka cena insektycydu.

Wskaźnik opłacalności zabiegów wahał się od 1,0 do 14,9 (średnio 4,1). Najniższą wartość $(1,0)$ uzyskał on na obiektach, na których zastosowano Sumi-Alpha 050 EC i Karate Zeon 050 EC, a najwyższą $(14,9)$ na obiekcie, gdzie zastosowano Biospin 120 SL. Wskaźnik opłacalności zabiegów określający część plonu, jaką należy przeznaczyć na pokrycie kosztów ochrony, na obiekcie z pełną ochroną, wyniósł średnio 14,9. Oznacza to, że koszty ochrony pszenicy ozimej w celu ograniczenia występowania chorób i szkodników są wysokie.

Procentowy wskaźnik kosztów najniższą wartość $(1,3)$ osiągnął na obiekcie, na którym zastosowano tylko insektycyd. Najwyższą wartość $(19,3)$ uzyskano na obiekcie traktowanym insektycydem Biospin 120 SL, co oznacza, że wykonane zabiegi ochrony roślin stanowią 19,3\% wartości uzyskanego plonu ziarna pszenicy z 1 hektara.

W 2013 roku w pszenicy ozimej uzyskano zwyżkę plonu ziarna od 6,5 do $1222 \mathrm{PLN} / \mathrm{ha}$ (średnio $472 \mathrm{PLN} / \mathrm{ha}$ ). Wskaźnik pokrycia kosztów wyniósł od 0,01 do 4,2. Najkorzystniejszą wartość $(4,2)$ uzyskano z obiektu, na którym zastosowano Artea 330 EC. Koszty poniesione na ochronę zwróciły się czterokrotnie. Wskaźnik opłacalności zabiegów wahał się od 1,3 do 19,4 (średnio 5,4). Najniższą wartość zanotowano na obiektach, na których zastosowano insektycydy: Karate 050 CS oraz Sumi-Alpha 050 EC. Koszty zabiegów ochronnych zostały zrównoważone wartością $1,3 \mathrm{dt}$ ziarna pszenicy. Procentowy wskaźnik kosztów wahał się od 3,5 do 54,0 i był najwyższy na obiekcie, na którym zastosowano środek Biospin $120 \mathrm{SL}$ $(54,0)$, a najniższy na obiektach, na których zastosowano pyretroidy $(3,5$ i 3,7$)$.

W 2014 roku w pszenicy ozimej uzyskano zwyżkę plonu ziarna od 7,5 do 652 PLN/ha. Wskaźnik pokrycia kosztów wyniósł od 0,05 do 7,4. Najwyższą wartość otrzymano $\mathrm{z}$ obiektu, na którym zastosowano $\mathrm{w}$ fazie kłoszenia pszenicy środki: Fastac 100 EC i Sumi-Alpha 050 EC. Koszty poniesione na ochronę zwróciły się 5- i 7-krotnie. Wskaźnik opłacalności zabiegów wahał się od 1,1 do 6,1 (średnio 2,4). Najniższą wartość uzyskano z obiektów, na których zastosowano insektycydy: Karate 050 CS, Fastac 100 EC i Sumi-Alpha 050 SC. Koszty zabiegów ochronnych zostały zrównoważone wartością 1,1 dt ziarna pszenicy. Procentowy wskaźnik kosztów wahał się od 1,2 do 6,5 i był najwyższy na obiekcie, na którym zastosowano pełną ochronę $(6,5)$, a najniższy na obiektach, na których zastosowano pyretroidy $(1,2$ i 1,3). 


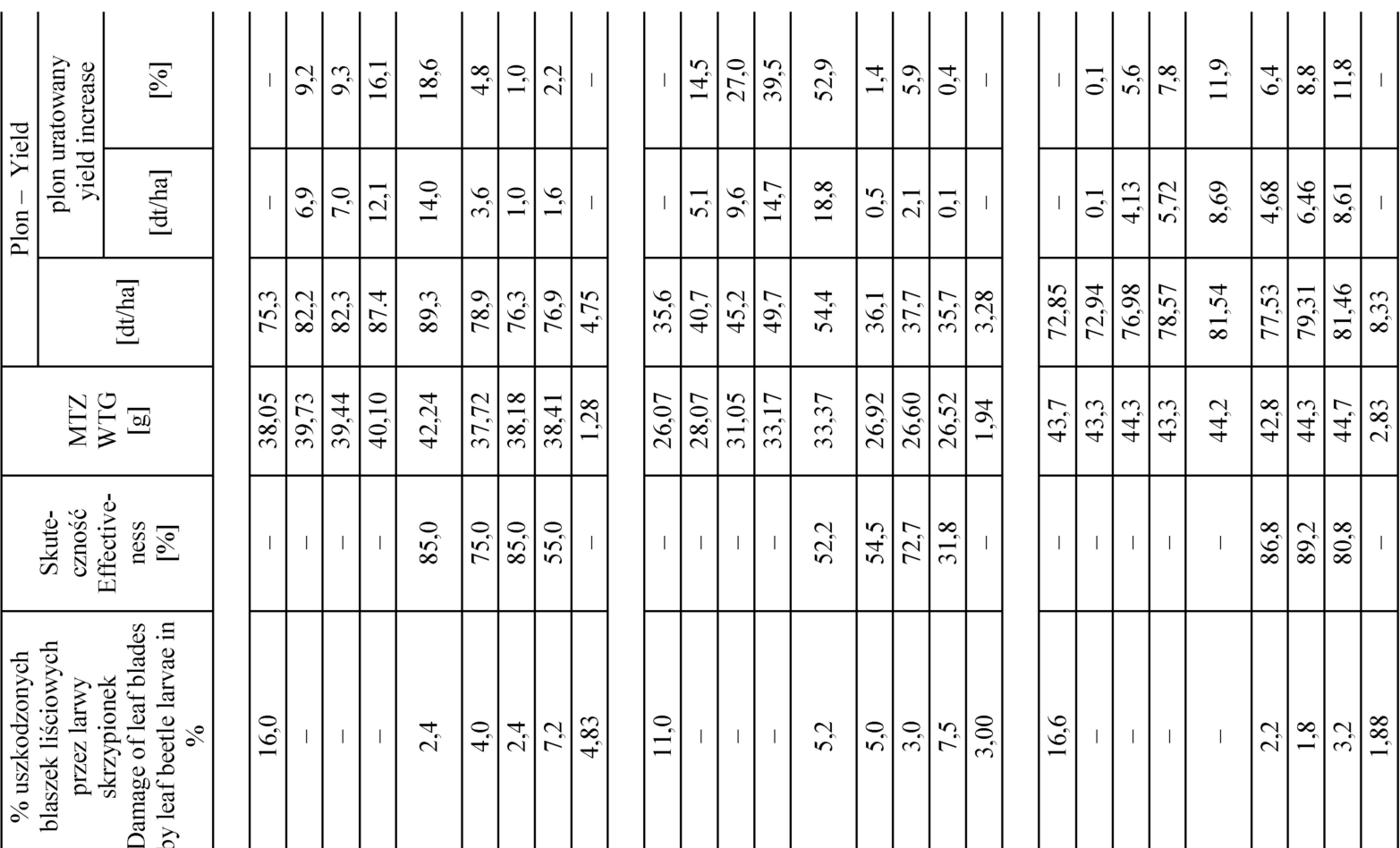

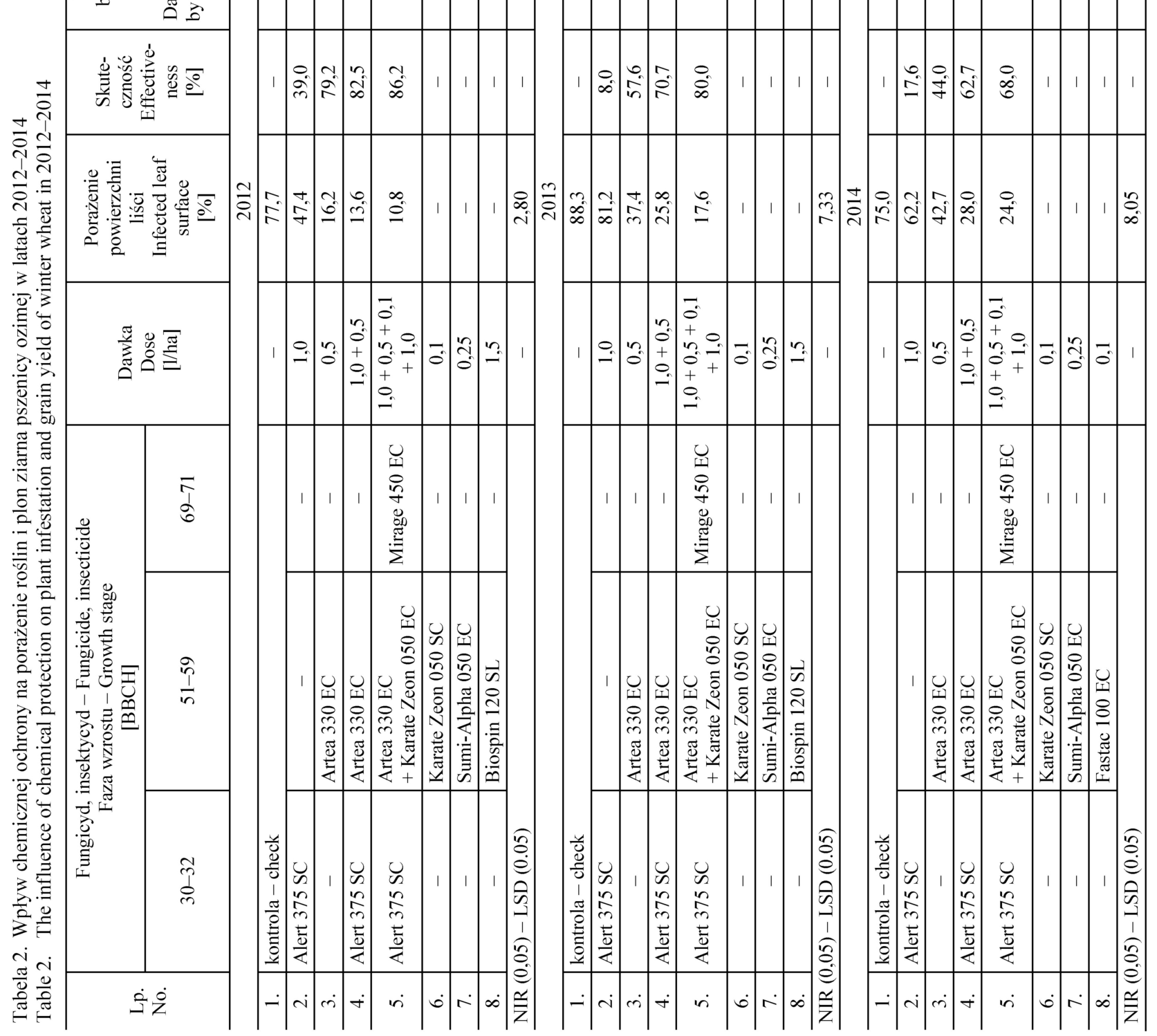


Tabela 3. Efektywność ekonomiczna zastosowanych fungicydów i insektycydów w pszenicy ozimej, w latach 2012-2014

Table 3. Economic efficiency of used fungicides and insecticide in winter wheat, in 2012-2014

\begin{tabular}{|c|c|c|c|c|c|c|c|c|c|}
\hline \multirow[t]{2}{*}{$\begin{array}{l}\text { Lp. } \\
\text { No. }\end{array}$} & \multicolumn{3}{|c|}{$\begin{array}{c}\text { Fungicyd, insektycyd - Fungicide, insecticide } \\
\text { Faza wzrostu - Growth stage } \\
{[\mathrm{BBCH}]}\end{array}$} & \multirow[t]{2}{*}{$\begin{array}{c}\text { Koszt } \\
\text { ochrony } \\
\text { Cost of } \\
\text { protection } \\
{[\text { PLN/ha }}\end{array}$} & \multicolumn{2}{|c|}{$\begin{array}{l}\text { Plon uratowany } \\
\text { Yield increase }\end{array}$} & \multicolumn{3}{|c|}{$\begin{array}{l}\text { Wskaźnik } \\
\text { Coefficient }\end{array}$} \\
\hline & $30-32$ & $51-59$ & $71-79$ & & [dt/ha] & {$[\mathrm{PLN} / \mathrm{ha}]$} & Wpk & $\mathrm{E}_{1}$ & $\mathrm{E}_{2}$ \\
\hline \multicolumn{10}{|c|}{2012} \\
\hline 1. & Alert $375 \mathrm{SC}$ & - & - & 158 & 6,9 & 586 & 3,7 & 1,8 & 2,2 \\
\hline 2. & - & Artea $330 \mathrm{EC}$ & - & 147 & 7,0 & 595 & 4,0 & 1,7 & 2,1 \\
\hline 3. & Alert $375 \mathrm{SC}$ & Artea $330 \mathrm{EC}$ & - & 305 & 12,1 & 1028 & 3,3 & 3,5 & 4,1 \\
\hline 4. & Alert $375 \mathrm{SC}$ & $\begin{array}{l}\text { Artea } 330 \text { EC } \\
+ \text { Karate Zeon } 050 \text { EC }\end{array}$ & Mirage $450 \mathrm{EC}$ & 457 & 14,0 & 1190 & 2,6 & 5,3 & 6,0 \\
\hline 5. & - & Karate Zeon 050 SC & - & 89 & 3,6 & 306 & 3,4 & 1,0 & 1,3 \\
\hline 6. & - & Sumi-Alpha 050 EC & - & 87 & 1,0 & 85 & 0,9 & 1,0 & 1,3 \\
\hline 7. & - & Biospin $120 \mathrm{SL}$ & - & 1267 & 1,6 & 136 & 0,1 & 14,9 & 19,3 \\
\hline \multicolumn{10}{|c|}{2013} \\
\hline 1. & Alert $375 \mathrm{SC}$ & - & - & 156 & 5,1 & 331 & 2,1 & 2,4 & 5,8 \\
\hline 2. & - & Artea $330 \mathrm{EC}$ & - & 147 & 9,6 & 624 & 4,2 & 2,2 & 5,0 \\
\hline 3. & Alert $375 \mathrm{SC}$ & Artea $330 \mathrm{EC}$ & - & 303 & 14,7 & 955 & 3,1 & 4,6 & 7,7 \\
\hline 4. & Alert $375 \mathrm{SC}$ & $\begin{array}{l}\text { Artea } 330 \mathrm{EC} \\
+ \text { Karate Zeon } 050 \mathrm{EC}\end{array}$ & Mirage $450 \mathrm{EC}$ & 457 & 18,8 & 1222 & 2,6 & 7,0 & 12,9 \\
\hline 5. & - & Karate Zeon 050 SC & - & 89 & 0,5 & 32,5 & 0,36 & 1,3 & 3,7 \\
\hline 6. & - & Sumi-Alpha 050 EC & - & 87 & 2,1 & 136,5 & 1,56 & 1,3 & 3,5 \\
\hline 7. & - & Biospin $120 \mathrm{SL}$ & - & 1267 & 0,1 & 6,5 & 0,01 & 19,4 & 54,0 \\
\hline \multicolumn{10}{|c|}{2014} \\
\hline 1. & Alert $375 \mathrm{SC}$ & - & - & 156 & 0,1 & 7,5 & 0,5 & 2,0 & 2,5 \\
\hline 2. & - & Artea $330 \mathrm{EC}$ & - & 147 & 4,13 & 307 & 2,0 & 1,9 & 2,2 \\
\hline 3. & Alert $375 \mathrm{SC}$ & Artea $330 \mathrm{EC}$ & - & 303 & 5,72 & 427 & 1,4 & 4,0 & 4,5 \\
\hline 4. & Alert $375 \mathrm{SC}$ & $\begin{array}{l}\text { Artea } 330 \text { EC } \\
+ \text { Karate Zeon } 050 \text { EC }\end{array}$ & Mirage 450 EC & 457 & 8,69 & 652 & 1,4 & 6,1 & 6,5 \\
\hline 5. & - & Karate Zeon 050 SC & - & 89 & 4,68 & 345 & 3,8 & 1,1 & 1,3 \\
\hline 6. & - & Sumi-Alpha 050 EC & - & 87 & 6,46 & 480 & 5,5 & 1,1 & 1,3 \\
\hline 7. & - & Fastac $100 \mathrm{EC}$ & - & 87 & 8,61 & 645 & 7,4 & 1,1 & 1,2 \\
\hline
\end{tabular}

Wpk - wskaźnik pokrycia kosztów - cost covering index

$\mathrm{E}_{1}$ - wskaźnik opłacalności zabiegów - treatment profitability index

$\mathrm{E}_{2}$ - procentowy wskaźnik kosztów - percentage index of the costs

W okresie prowadzonych badań uzyskano wzrost wartości plonu uratowanego ziarna pszenicy, ale nie w każdym roku pozwolił on pokryć koszty ochrony i zapewnić zysk. Natomiast wysokie wskaźniki opłacalności zabiegów na obiektach z pełną ochroną, sygnalizują coraz mniej korzystną relację między kosztami ochrony (wysoka cena fungicydów) a ceną zbytu ziarna pszenicy, co potwierdzają wcześniejsze badania niektórych autorów (Juszczak i Krasiński 1998; Kaniuczak 2000). Wyniki wielu badań wykonanych przez różnych autorów wskazują, że zastosowanie właściwej ochrony zbóż, odpowiednie dobranie terminu zabiegu, a także użycie skutecznych insektycydów i fungicydów pozwala zapewnić znaczny wzrost plonu oraz poprawę parametrów ziarna (Jańczak i wsp. 1990; Kaniuczak 1997, 2008; Korbas 1998; Kaniuczak i Matłosz 1999; Kurowski i Hruszka 2004).

\section{Wnioski / Conclusions}

1. W południowo-wschodniej Polsce zasiewy pszenicy ozimej uszkadzane są przez wiele agrofagów, spośród których ważną pozycję zajmują sprawcy chorób. Zabiegi wykonane fungicydami korzystnie wpływały na zdrowotność liści i źdźbła. Lepsze efekty uzyskiwano po zastosowaniu dwóch zabiegów, jednak już jeden zabieg zdecydowanie polepszał zdrowotność roślin i zwiększał plon. Zastosowane zabiegi we 
wszystkich latach utrzymywały dłużej zieloną powierzchnię górnych liści pszenicy ozimej.

2. W latach badań choroby powodowane przez grzyby chorobotwórcze stanowiły duże zagrożenie dla roślin pszenicy opanowując w wysokim procencie powierzchnię blaszek liści flagowych i podflagowych.

3. Fungicydy i insektycydy wpłynęły na znaczne zmniejszenie powierzchni zniszczonych liści przez choroby grzybowe i larwy skrzypionek. Istotną zwyżkę plonów oraz MTZ na skutek zastosowania fungicydów stwierdzono na obiektach, na których użyto fungicydy zarówno w dwóch, jak i w trzech terminach.
4. Wielkość produkcji uratowanej w wyniku zastosowania zabiegów ochrony roślin była zależna od intensywności prowadzonych zabiegów w pszenicy ozimej.

5. Opłacalność chemicznych zabiegów ochronnych wyrażona wskaźnikami była zróżnicowana na poszczególnych kombinacjach i w latach badań. Stosunkowo wysoki wskaźnik opłacalności zabiegów sygnalizuje coraz mniej korzystną relację między kosztami ochrony (wysoka cena fungicydów i niektórych insektycydów) a ceną zbytu ziarna pszenicy.

\section{Literatura / References}

Danyte V., Pecio A. 2009. Wpływ warunków pogody na porażenie zbóż ozimych patogenami liści i kłosów. [The influence of weather conditions on infection of winter cereals with leaf and ear pathogens]. Progress in Plant Protection/Postępy w Ochronie Roślin 49 (1): 191-196.

Głazek M., Krzyzińska B., Mączyńska A., Banachowska J. 2006. Zmiany w zagrożeniach uprawy pszenicy ozimej przez choroby grzybowe na przestrzeni lat 1995-2005 w rejonie Polski południowo-środkowej. [Changing threats to winter wheat cultures by fungal diseases in the years 1995-2005 in the region of middle-southern Poland]. Progress in Plant Protection/Postępy w Ochronie Roślin 46 (1): 347-353.

Golinowska M. 2009. Ekonomika ochrony roślin w teorii i praktyce. [Economics of plant protection in theory and practice]. Progress in Plant Protection/Postępy w Ochronie Roślin 49 (1): 23-33.

Jaczewska A. 1993. Straty plonu pszenicy powodowane przez kompleks chorób liści i kłosa. Materiały 33. Sesji Naukowej Instytutu Ochrony Roślin, cz. 2: 147-150.

Jaczewska-Kalicka A. 2008. Wpływ zmiennych warunków klimatycznych na występowanie i szkodliwość grzybów patogenicznych w uprawie pszenicy ozimej. Zeszyty Problemowe Postępów Nauk Rolniczych 531: 63-69.

Jańczak C., Pokacka Z., Ruszkowska M., Wachowiak M. 1990. Chemiczna ochrona zbóż przed chorobami i szkodnikami. Instrukcja upowszechnieniowa. Instytut Ochrony Roślin, Poznań, 41 ss.

Jończyk K. 1999. Efektywność chemicznego zwalczania chorób grzybowych w uprawie pszenicy ozimej i żyta. Pamiętnik Puławski 114: $151-158$

Juszczak M., Krasiński T. 1998. Ekonomiczna ocena ochrony pszenicy ozimej i rzepaku ozimego. [Economic estimation of winter wheat and winter rape protection]. Progress in Plant Protection/Postępy w Ochronie Roślin 38 (1): 247-257.

Kaniuczak Z. 1997. Noxiousness and control of Oulema spp. larve in the spring wheat. Journal of Plant Protection Research 37 (1/2): 99-103.

Kaniuczak Z. 2000. Ocena ekonomicznej efektywności stosowania fungicydów w zbożach. Roczniki Akademii Rolniczej 321, Ogrodnictwo 30: 49-54

Kaniuczak Z. 2008. Skuteczność biologiczna oraz wskaźniki ekonomiczne chemicznego zwalczania szkodników w pszenicy jarej. [Biological effectiveness and economic indicators of chemical control of pests in spring wheat]. Progress in Plant Protection/Postępy w Ochronie Roślin 48 (1): 109-113.

Kaniuczak Z., Matłosz I. 1999. Efekty produkcyjne i ekonomiczne zwalczania szkodników w zbożach. Pamiętnik Puławski 114: $159-165$

King J.E., Cook R.J., Melville S.C. 1983. A review of Septoria diseases of wheat and barley. Annals of Applied Biology 103: 345-373.

Korbas M. 1998. Choroby i szkodniki zbóż. Multum, Poznań, 88 ss.

Kurowski T.P., Hruszka M. 2004. Zdrowotność i plonowanie pszenżyta ozimego w łanie chronionym zabiegami chemicznymi i proekologicznymi. [Healthiness state and yielding of winter triticale protected by chemical and pro-ecological treatment]. Progress in Plant Protection/Postępy w Ochronie Roślin 44 (2): 896-899.

Lipa J.J. 1999. Nowoczesna ochrona zbóż. [Modern protection of cereal crops]. Pamiętnik Puławski 114: 241-259.

Lisowicz F., Kaniuczak Z., Śnieżek G. 1993. Metody sygnalizacji i progi zwalczania najważniejszych chorób i szkodników zbóż. Ośrodek Doradztwa Rolniczego, Boguchwała: 1-12.

Podolska G., Szypuła G. 2002. Plonowanie i wartość technologiczna ziarna pszenicy ozimej w zależności od sposobu ochrony przed chorobami i chwastami. Pamiętnik Puławski 130: 587-596.

Pokacka Z. 1985. Badania nad plamistościami liści pszenicy ze szczególnym uwzględnieniem roli Septoria nodorum Berk. Prace Naukowe Instytutu Ochrony Roślin 27 (2): 5-31.

Walczak F. 2010. Groźne szkodniki zbóż i terminy ich zwalczania. Wieś Jutra 4 (141): 30-34.

Wałkowski W., Mrówczyński M., Wachowiak H., Drzewiecki S. 2000. Badania ścisłe i wdrożeniowe nad zastosowaniem nowoczesnych insektycydów do zwalczania skrzypionek zbożowych (Lema melanopa L. et L. cyanella Voet.). [Plot and practical studies on the using of the modern insecticides to control of the cereal leaf beatles (Lema melanopa L. et L. cyanella Voet.)]. Progress in Plant Protection/Postępy w Ochronie Roślin 40 (2): 460-463. 